\title{
Cele remediacji a rola akredytowanych laboratoriów - aspekty praktyczne
}

\section{Wstęp}

Remediacja nie jest terminem spotykanym często, szczególnie poza zakresem związanym z szeroko pojętą ochroną środowiska. Obowiązek remediacji w obecnym kształcie został wprowadzony ustawą z dnia 11 lipca 2014 r. o zmianie ustawy — Prawo ochrony środowiska oraz niektórych innych ustaw $^{1}$. Ten akt prawny miał na celu w zakresie swojej regulacji wdrożenie dyrektywy Parlamentu Europejskiego i Rady 2010/75/UE z dnia 24 listopada 2010 r. w sprawie emisji przemysłowych (zintegrowane zapobieganie zanieczyszczeniom i ich kontrola) ${ }^{2}$. Obecnie remediację regulują trzy podstawowe akty prawne:

- ustawa z dnia 27 kwietnia 2001 r. - Prawo ochrony środowiska ${ }^{3}$;

- ustawa z dnia 13 kwietnia 2007 r. o zapobieganiu szkodom w środowisku i ich naprawie ${ }^{4}$;

- rozporządzenie Ministra Środowiska z dnia 1 września 2016 r. w sprawie sposobu prowadzenia oceny zanieczyszczenia powierzchni ziemi ${ }^{5}$.

\footnotetext{
1 Dz.U. poz. 1101.

2 Dz.Urz. UE L 334 z dnia 17 grudnia 2010 r., s. 17, ze zm.

3 T.j. Dz.U. 2020, poz. 1219 ze zm., dalej: pr.o.ś.

4 T.j. Dz.U. 2019, poz. 1862 ze zm., dalej: ustawa naprawcza.

5 Dz.U. poz. 1395, dalej: Rozporządzenie.
} 
Regulacje te wprowadziły rozwiązania analogiczne do tych, które można spotkać w innych krajach europejskich. W szczególności zaimplementowano do systemu prawnego:

- definicję remediacji;

- przepisy dotyczące oceny ryzyka dla zdrowia ludzi i środowiska;

- uregulowanie odpowiedzialności podmiotów korzystających ze środowiska za zanieczyszczenie

- wprowadzenia metod oceny zanieczyszczenia powierzchni ziemi.

Przepisy regulujące remediację są $\mathrm{w}$ doktrynie uznawane za dość precyzyjne i przejrzyste, jednak w toku swojej praktyki zawodowej autor spotkał się z istotnymi odmiennościami $\mathrm{w}$ interpretacji tychże przepisów, szczególnie w zakresie roli tzw. akredytowanego laboratorium oraz certyfikowanych jednostek badawczych $\mathrm{w}$ procesie remediacji. W związku z powyższym artykuł ten ma za zasadnie opisać problemy praktyczne, o których wspomniano wcześniej, a autor spróbuje udzielić wskazówek de lege lata oraz de lege ferenda pomocnych w rozwiązaniu tych problemów. Omówienie niniejszych kwestii wymaga jednak odpowiedniego kontekstu, konieczne zatem jest przedstawienie pokrótce instytucji remediacji oraz jej ram prawnych.

\section{Czym jest remediacja}

Aby umieścić rozważania praktyczne w odpowiednim kontekście, należy najpierw w skrócie omówić instytucję remediacji oraz rolę, jaką pełnią w niej akredytowane laboratoria oraz certyfikowane jednostki badawcze.

W ustawie - Prawo ochrony środowiska znajdziemy definicję legalną remediacji. Stosownie do art. 3 pkt 31b) przez remediację rozumie się: „,poddanie gleby, ziemi i wód gruntowych działaniom mającym na celu usunięcie lub zmniejszenie ilości substancji powodujących ryzyko, ich kontrolowanie oraz ograniczenie rozprzestrzeniania się, tak aby teren zanieczyszczony przestał stwarzać zagrożenie dla zdrowia ludzi lub stanu środowiska, z uwzględnieniem obecnego i, o ile jest to możliwe, planowanego w przyszłości sposobu użytkowania terenu; remediacja może polegać na samooczyszczaniu, jeżeli przynosi największe korzyści dla środowiska".

Do powyższej definicji odwołuje się także ustawa naprawcza w art. 6 pkt. 9b). Zgodnie z tym aktem prawnym remediacja jest jednym z działań naprawczych,

${ }^{6} \mathrm{Wg}$ art. 3 pkt 49) pr.o.ś. rozumie się przez to emisję, która może być szkodliwa dla zdrowia ludzi lub stanu środowiska, może powodować szkodę w dobrach materialnych, może pogarszać walory estetyczne środowiska lub może kolidować z innymi, uzasadnionymi sposobami korzystania ze środowiska. 
zdefiniowanych w art. 6 pkt. 3), tj.: ,wszelkie działania, w tym działania ograniczające lub tymczasowe, podejmowane $\mathrm{w}$ celu naprawy lub zastąpienia $\mathrm{w}$ równoważny sposób elementów przyrodniczych lub ich funkcji, które uległy szkodzie, a także działania kompensacyjne; do działań naprawczych zalicza się w szczególności przeprowadzenie remediacji, przywracanie naturalnego ukształtowania terenu, zalesianie, zadrzewianie lub tworzenie skupień roślinności, reintrodukcję zniszczonych gatunków, prowadzące do usunięcia zagrożenia dla zdrowia ludzi oraz przywracania równowagi przyrodniczej na danym terenie".

Remediacja może oczywiście zostać przeprowadzona, jeżeli chodzi o jej aspekt techniczny, na wiele sposobów, zależnie od tego, z jakimi skażeniami mamy do czynienia. Najczęściej spotykane metody remediacji to?:

- fizyczne - ekstrakcja, sortowanie, elektrooczyszczanie;

- chemiczne - odmywanie, dehalogenacja, hydroliza, stabilizacja (solidyfikacja, sorpcja);

- elektrochemiczne;

- termiczne - odparowanie (desorpcja termiczna), zeszklenie, spalanie;

- biologiczne - bioremediacja, fitoremediacja, entomoremediacja.

Jak zatem wynika z powyższego zestawienia, metod remediacji jest sporo, a wybór metody zależy od wielu czynników, m.in. takich, jak rodzaj zanieczyszczenia, gruntu, istniejących zabudowań, oczekiwanej szybkości uzyskania efektów. Wiele firm zajmujących się profesjonalnie remediacją posiada także autorskie metody, np. biopreparaty, których działanie jest objęte tajemnicą handlową. W remediacji mogą być też wykorzystywane rośliny ${ }^{8}$, insekty ${ }^{9}$ oraz mikroorganizmy (bakterie, archeony, grzyby).

Ponadto, metody remediacji możemy wyróżnić jeszcze ze względu na jeden czynnik, tj. miejsce przeprowadzenia. Podział ten jest dychotomiczny i obejmuje dwa rodzaje remediacji:

- in situ - prowadzenie procesu remediacji w miejscu występowania zanieczyszczenia, bez konieczności przemieszczania gruntu;

- ex situ - czyli wymianę skażonego gruntu i dalsze zagospodarowanie powstałego odpadu poza terenem jego wytworzenia.

${ }^{7}$ B. Smolińska, Metody oczyszczania gleb zanieczyszczonych rtęcia, „Zeszyty Naukowe Politechniki Łódzkiej. Chemia Spożywcza i Biotechnologia” 2010, nr 74, s. 121-136.

8 A. Abratowska, Armeria maritima - gatunek roślin przystosowany do wzrostu na glebach skażonych metalami ciężkimi, „Kosmos” 2006, Vol. 55 (2-3), s. 217-227.

9 P. Bulak et al., Hermetia illucens as a new and promising species for use in entomoremediation, „Science of The Total Environment” 2018, Vol. 633, s. 912-919, DOI: 10.1016/j. scitotenv.2018.03.252. 


\section{Kiedy trzeba dokonać remediacji}

Zgodnie z art. 101 pkt. 3 pr.o.ś. remediacja jest jednym ze sposobów ochrony ziemi. Oczywiście w pierwszej kolejności należy zapobiegać zanieczyszczeniu gleby, natomiast w przypadku gdy już do tego doszło, przywrócenie jej do pierwotnego (lub bliskiego pierwotnemu) stanu wymaga działań remediacyjnych. W celu identyfikacji terenów, które wymagają remediacji, dokonywana jest tzw. ocena zanieczyszczenia powierzchni ziemi, oparta na podstawie pomiaru zawartości substancji powodujących ryzyko w glebie lub w ziemi i porównania ilości zanieczyszczeń z parametrami dopuszczalnymi. W art. 101a ust. 1-4 pr.o.ś. wskazano, że kryterium uzasadniającym podjęcie działań remediacyjnych „będzie przekroczenie dopuszczalnych zawartości substancji powodujących ryzyko, z uwzględnieniem funkcji pełnionej przez powierzchnię ziemi oraz tzw. tła geochemicznego, czyli naturalnej zawartości substancji powodujących ryzyko w glebie, ziemi lub wodach gruntowych (dotyczy to tylko pewnych substancji, np. niektórych metali; duża część substancji powodujących ryzyko jest pochodzenia antropogenicznego i nie występuje w środowisku w sposób naturalny)" ${ }^{" 10}$.

Co do zasady oczywiście nie każdy władający ${ }^{11}$ powierzchnią ziemi jest obowiązany do dokonania badań zanieczyszczenia powierzchni ziemi. Stosownie do obowiązujących przepisów to organy inspekcji ochrony środowiska w ramach państwowego monitoringu środowiska dokonują oceny oraz badań i obserwacji stanu gleby i ziemi. W praktyce obejmuje to następujące sytuacje:

- w razie potrzeby starosta może wykonać pierwszy etap badań zanieczyszczenia gleby i ziemi - jest to wypadkowa ustawowo uregulowanej konieczności prowadzenia wykazu potencjalnych historycznych zanieczyszczeń powierzchni ziemi;

- właściwy regionalny dyrektor ochrony środowiska może wykonać badania w celu potwierdzenia występowania historycznego zanieczyszczenia powierzchni ziemi, potwierdzenia występowania bezpośredniego zagrożenia szkodą w środowisku lub potwierdzenia szkody;

- zgodnie z ustawą, prowadzący instalację, która wymaga uzyskania pozwolenia zintegrowanego, dokonuje oceny zanieczyszczenia powierzchni ziemi w ramach sporządzanych raportów: początkowego i końcowego;

- ponadto obowiązek wykonania badań zanieczyszczenia powierzchni ziemi może powstać na skutek decyzji nałożonej przez regionalnego dyrektora ochrony środowiska;

10 Uzasadnienie projektu ustawy o zmianie ustawy — Prawo ochrony środowiska oraz niektórych innych ustaw, druk sejm. nr 2167, Sejm RP VII kadencji.

$11 \mathrm{Wg}$ art. 3 pkt. 44) pr.o.ś. rozumie się przez to właściciela nieruchomości, a jeżeli w ewidencji gruntów i budynków prowadzonej na podstawie ustawy Prawo geodezyjne i kartograficzne ujawniono inny podmiot władający gruntem - podmiot ujawniony jako władający. 
- finalnie, w przypadku bezpośredniego zagrożenia dla środowiska lub szkody w środowisku, organ ochrony środowiska może nakazać w drodze decyzji obowiązek przeprowadzenia badań: na przedsiębiorcę prowadzącego działalność stwarzającą ryzyko szkody lub prowadzącego inną działalność, która jest przyczyną bezpośredniego zagrożenia szkodą, oraz gdy szkoda dotyczy gatunków chronionych i siedlisk przyrodniczych oraz szkody w środowisku, które wystąpiły z winy podmiotu korzystającego ze środowiska.

Co istotne, badania zanieczyszczenia gleby i ziemi, wskazane powyżej, wykonuje laboratorium, o którym mowa w art. 147a ust. 1 pkt 1 lub ust. la, tj. akredytowane laboratorium w rozumieniu ustawy z dnia 30 sierpnia $2002 \mathrm{r}$. o systemie oceny zgodności ${ }^{12}$, dalej zwane ,akredytowanym laboratorium”.

Jeżeli wyniki oceny wskażą, że na powierzchni ziemi występuje tzw. historyczne zanieczyszczenie powierzchni ziemi ${ }^{13}$, to co do zasady władający powierzchnią ziemi, na której występuje to zanieczyszczenie, jest obowiązany do zgłoszenia tego faktu właściwemu regionalnemu dyrektorowi ochrony środowiska oraz do przeprowadzenia remediacji. Jednakże, jeżeli władający powierzchnią ziemi wykaże, że historyczne zanieczyszczenie powierzchni ziemi dokonane po dniu objęcia przez niego władania spowodował inny wskazany podmiot, zwany dalej ,,innym sprawcą”, obowiązek przeprowadzenia remediacji spoczywa na tym podmiocie. Ponadto jeżeli zanieczyszczenie zostało spowodowane przez podmiot trzeci za zgodą lub wiedzą władającego powierzchnią ziemi, władający powierzchnią ziemi jest obowiązany do przeprowadzenia remediacji solidarnie z innym sprawcą.

Istnieją sytuacje, w których to właściwy regionalny dyrektor ochrony środowiska przeprowadza remediację. Są to następujące przypadki:

- nie można wszcząć wobec władającego powierzchnią ziemi postępowania egzekucyjnego dotyczącego obowiązku przeprowadzenia remediacji albo egzekucja okazała się bezskuteczna;

- władający powierzchnią ziemi wykaże, że zanieczyszczenie dokonane po dniu objęcia przez niego władania spowodował inny sprawca, wobec którego nie można wszcząc postępowania egzekucyjnego dotyczącego obowiązku przeprowadzenia remediacji, lub egzekucja okazała się bezskuteczna;

- władający powierzchnią ziemi dokonał zgłoszenia na podstawie art. 12 ustawy z dnia 27 lipca 2001 r. o wprowadzeniu ustawy - Prawo ochrony środo-

${ }_{12}$ T.j. Dz.U. 2019, poz. 155 ze zm., dalej: u.s.o.z.

${ }^{13}$ Rozumie się przez to zanieczyszczenie powierzchni ziemi zaistniałe przed dniem 30 kwietnia 2007 r. lub wynikające z działalności, która została zakończona przed dniem 30 kwietnia 2007 r.; rozumie się przez to także szkodę $\mathrm{w}$ środowisku w powierzchni ziemi w rozumieniu art. 6 pkt 11 lit. c ustawy z dnia 13 kwietnia 2007 r. o zapobieganiu szkodom w środowisku i ich naprawie (Dz.U. 2019, poz. 1862 oraz Dz.U. 2020, poz. 284.), która została spowodowana przez emisję lub zdarzenie, od którego upłynęło więcej niż 30 lat. 
wiska, ustawy o odpadach oraz o zmianie niektórych ustaw ${ }^{14}$, a także starosta uwzględnił zgłoszenie $w$ rejestrze zawierającym informacje o terenach, gdzie stwierdzono przekroczenie standardów jakości gleby lub ziemi, z wyszczególnieniem terenów, na których obowiązek rekultywacji obciążał starostę (chodzi o sytuację, gdy władający powierzchnią ziemi zgłosił w dniu wejścia w życie ww. ustawy, że przed jej wejściem w życie nastąpiło odpowiednio zanieczyszczenie ziemi lub gleby albo niekorzystne przekształcenie naturalnego ukształtowania terenu spowodowane przez inny podmiot);

- z uwagi na zagrożenie dla zdrowia ludzi lub możliwość zaistnienia nieodwracalnych szkód w środowisku jest konieczne niezwłoczne jej przeprowadzenie.

\section{Procedura przeprowadzenia remediacji}

Po ustaleniu, że remediacja jest konieczna, oraz określeniu podmiotu odpowiedzialnego za jej przeprowadzenie, należy sporządzić jej plan. Władający powierzchnią ziemi lub inny sprawca, obowiązany do przeprowadzenia remediacji historycznego zanieczyszczenia powierzchni ziemi, jest obowiązany do przedłożenia regionalnemu dyrektorowi ochrony środowiska wniosku o wydanie decyzji ustalającej plan remediacji, który zawiera projekt tego dokumentu.

Plan remediacji podlega zatwierdzeniu przez właściwego regionalnego dyrektora ochrony środowiska i zawiera co do zasady informacje o:

- terenie wymagającym przeprowadzenia remediacji, poprzez wskazanie adresu i numerów działek ewidencyjnych oraz jego powierzchni;

- nazwach substancji powodujących ryzyko oraz ich zawartości w glebie i w ziemi, do jakich doprowadzić ma remediacja;

- sposób (np. technologię oraz metody jej zastosowania) przeprowadzenia remediacji;

- termin rozpoczęcia i zakończenia remediacji;

- sposób potwierdzenia przeprowadzenia remediacji oraz termin przedłożenia dokumentacji z jej przeprowadzenia, w tym wyników badań zanieczyszczenia gleby i ziemi wykonanych przez akredytowane laboratorium.

Co zatem niezmiernie istotne z punktu widzenia omawianej tematyki, potwierdzenie remediacji uzależnione jest w dużym stopniu od wyników badań zanieczyszczenia gleby i ziemi wykonanych przez akredytowane laboratorium.

Po ustaleniu planu remediacji podmiot obowiązany do jej przeprowadzenia powinien wykonać zawarte w planie działania. Po ich wykonaniu możliwa jest ocena przeprowadzenia remediacji, której dokonuje właściwy regionalny dy-

\footnotetext{
${ }^{14}$ Dz.U. poz. 1085 ze zm.
} 
rektor ochrony środowiska, a polega ona na stwierdzeniu zgodności remediacji $\mathrm{z}$ ustalonym planem remediacji. W przypadku gdy stwierdzono niezgodność przeprowadzonej remediacji z ustalonym planem remediacji, stosuje się przepisy o postępowaniu egzekucyjnym w administracji (powstaje więc możliwość nałożenia grzywny w celu przymuszenia lub nawet wykonania zastępczego).

\section{Kontrola prawidłowości przeprowadzenia remediacji}

Jak wskazano powyżej, pr.o.ś. przewiduje ocenę zgodności remediacji $\mathrm{z}$ ustalonym planem remediacji przez właściwego regionalnego dyrektora ochrony środowiska. Wydaje się to nawet niezbędne, gdyż lekceważony mógłby być obowiązek przeprowadzenia remediacji zgodnie z planem, gdyby nie był to obowiązek egzekwowalny. Jednakże regulacja ta w praktyce jest nazbyt ogólna $i$, jak się wydaje, nie wprowadza instrumentów, które pozwalają faktycznie dokonać sprawdzenia prawidłowości remediacji przez organ, jakim jest regionalny dyrektor ochrony środowiska. Zgodnie z art. 379 ust. 1 pr.o.ś. marszałek województwa, starosta oraz wójt, burmistrz lub prezydent miasta sprawują kontrolę przestrzegania i stosowania przepisów o ochronie środowiska w zakresie objętym właściwością tych organów. Tym samym należy zauważyć, że regionalny dyrektor ochrony środowiska nie został w art. 379 ust. 1 ustawy pr.o.ś. zaliczony do grona organów kontroli i nie przysługują mu uprawnienia $\mathrm{z}$ tego tytułu, w tym uprawnienie do wydawania zaleceń pokontrolnych. W związku $\mathrm{z}$ powyższym nie prowadzi kontroli $\mathrm{w}$ zakresie przepisów ochrony środowiska pozostających $\mathrm{w}$ jego właściwości ${ }^{15}$. Jeżeli zatem podjąłby takie działania $\mathrm{w}$ omawianej kategorii spraw, to nie miałyby one umocowania prawnego. Jak się wydaje, w takim przypadku regionalny dyrektor ochrony środowiska powinien wystąpić do właściwego miejscowo wojewódzkiego inspektora ochrony środowiska o przeprowadzenie kontroli prawidłowości wykonania remediacji, jednak w takim przypadku ustaleń faktycznych będzie dokonywał inny organ niż ten, który ustalał plan remediacji, co nie wydaje się rozwiązaniem fortunnym. Brak także wskazań, w jakiej formie prawnej regionalny dyrektor ochrony środowiska ma dokonać stwierdzenia prawidłowości wykonania remediacji lub odmowy takiego stwierdzenia. Nie zostało także określone, w jaki sposób organ ten może badać konkretne działania podmiotu obowiązanego, np. ilość wykonanych w gruncie piezometrów, rodzaj zastosowanego biopreparatu, czy też ilość pobranych przez akredytowane laboratorium próbek. Pamiętajmy,

${ }^{15}$ Zob. http://orka2.sejm.gov.pl/INT8.nsf/klucz/283B83FF/\%24FILE/z01640-o1.pdf [dostęp: 30.10.2020]. 
że akredytowane laboratorium, w przypadku remediacji nieprzeprowadzanej przez regionalnego dyrektora ochrony środowiska, działa na zlecenie i koszt podmiotu obowiązanego do przeprowadzenia remediacji. Jednakże, w praktyce nierzadko odnotowuje się przypadki, w których badania były dokonywane w sposób określony przez podmiot obowiązany i pomimo tego, że remediacja została przeprowadzona niezgodnie z planem remediacji, wyniki takich badań były pozytywne. Organ ochrony środowiska musi mieć możliwość ingerować w tego typu działania i je nadzorować, aby remediacja dała realne skutki, a nie tylko pozorne, zatwierdzone przez akredytowane laboratorium, wybrane przez podmiot obowiązany. W praktyce jednakże bardzo często tak jest, tj. regionalny dyrektor ochrony środowiska, po przedstawieniu mu pozytywnych badań akredytowanego laboratorium, zatwierdza przeprowadzoną remediację jako prawidłową, nie dokonując weryfikacji, czy na terenie nadal występują zanieczyszczenia (i czy badanie laboratoryjne przeprowadzono w prawidłowy sposób). To sprowadza akredytowane laboratorium niejako do roli superarbitra, który de facto dokonuje oceny prawidłowości remediacji zamiast organu administracji. Zdarzały się w praktyce sytuacje, gdy właściciel gruntu zlecił swoje badania jednemu laboratorium (i dały wynik negatywny), a wykonawca usługi bioremediacji legitymował się wynikami innego laboratorium, któremu zlecił badanie, $\mathrm{i}$ one miały pozytywny wynik. $\mathrm{W}$ tym zakresie istotne stanowisko wyraził Naczelny Sąd Administracyjny w wyroku z dnia 30 marca 2017 r. ${ }^{16}$, stawiając następujące tezy:

- Nie jest uzasadnione twierdzenie, że „obowiązek przeprowadzenia badań przez laboratorium, które spełnia warunki określone w art. 147a pr.o.ś. spoczywa, jedynie na wnioskodawcy. Takie twierdzenie stawiałoby organ w uprzywilejowanej w stosunku do wnioskodawcy pozycji co do środków dowodowych, a to byłoby sprzeczne z zasadą pogłębiania zaufania obywateli do organów państwa wyrażonej w art. 8 k.p.a.”.

- „Złożenie stosownego wniosku przez posiadacza odpadów nie zwalnia organu administracji od dokonania oceny merytorycznej wniosku, a zatem jeśli organ poweźmie wątpliwości co do wyników badań złożonych przez wnioskodawcę, może przeprowadzić inne dowody, które pozwolą na ocenę zasadności wniosku".

- „Skoro ustawodawca nałożył na wnioskodawcę obowiązek udokumentowania jego wniosku badaniami przeprowadzonymi przez akredytowane laboratorium, to zakwestionowanie takiego dowodu może odbyć się jedynie po przeprowadzeniu dowodu z badań laboratoryjnych pochodzących z takiego samego (akredytowanego) laboratorium".

${ }^{16}$ Wyrok NSA z dnia 30 marca 2017 r., sygn. akt II OSK 1820/15, Centralna Baza Orzeczeń Sądów Administracyjnych. 
Co prawda zapatrywania powyższe zostały wyrażone na gruncie innych przepisów, tj. ustawy z dnia 14 grudnia 2012 r. o odpadach ${ }^{17}$, jednak występują tutaj pewne analogie i należy podzielić transponowanie go na procedurę przeprowadzenia remediacji. $W$ ramach oceny prawidłowości remediacji regionalny dyrektor ochrony środowiska powinien mieć możliwość zakwestionowania wyników badań przeprowadzonego przez akredytowane laboratorium i np. przeprowadzenie $w$ ramach kontroli dowodów $\mathrm{z}$ badania wykonanego przez inne akredytowane laboratorium. Celem remediacji nie jest przecież uzyskanie pozytywnego wyniku badania, co do którego organ nie może nawet sprawdzić, jak zostało przeprowadzone, a faktyczne usunięcie/zmniejszenie ilości zanieczyszczeń powierzchni ziemi. Problemy wskazywane powyżej ukazują, jak niedoskonała jest regulacja art. 101n pr.o.ś., dotyczącego oceny prawidłowości remediacji.

\section{Wnioski}

Z przedstawionych $w$ tym artykule rozważań wynika, że procedura remediacji, pomimo tego, że uregulowana została dość szczegółowo, nie zawiera dostatecznie precyzyjnych i stanowczych rozwiązań, umożliwiających realne, a nie tylko pozorne, zweryfikowanie wykonania remediacji zgodnie z planem remediacji. Jak się wydaje, regionalnym dyrektorom ochrony środowiska nie przyznano dostatecznych kompetencji kontrolnych, a zbyt dużą rolę $\mathrm{w}$ toku remediacji pełnią wyniki badania akredytowanych laboratoriów, których w praktyce regionalny dyrektor ochrony środowiska nie ma wyraźnej możliwości kwestionować, a w konsekwencji instrument w postaci remediacji nie spełnia swojej ustawowej roli. De lege ferenda należy zatem postulować o następujące zmiany:

- doprecyzowanie i rozszerzenie procedury dotyczącej weryfikacji prawidłowości przeprowadzonej remediacji;

- przyznanie regionalnym dyrektorom ochrony środowiska uprawnień kontrolnych w zakresie remediacji;

- umożliwienie weryfikacji wyników badania akredytowanego laboratorium poprzez wprowadzenie możliwości przeprowadzania przez organy administracji stosownych dowodów;

- umożliwienie regionalnym dyrektorom ochrony środowiska uczestniczenia w wykonywaniu badania przez akredytowane laboratorium w celu weryfikacji prawidłowości wykonania takiego badania;

- uregulowanie formy prawnej, w jakiej regionalny dyrektor ochrony środowiska ma ocenić zgodność remediacji z planem remediacji - pozwoli to także na

${ }_{17}$ T.j. Dz.U. 2020, poz. 797 ze zm. 
lepszą ochronę interesu podmiotów obowiązanych, wyraźnie regulując sposób zaskarżenia takiego aktu administracyjnego.

Wprowadzenie powyższych postulatów w życie z pewnością wyjaśniłoby wiele wątpliwości w zakresie remediacji oraz doprowadziłoby do pożądanej sytuacji, gdy formalne potwierdzenie remediacji oznaczałoby z większą pewnością także faktyczne jej dokonanie.

\title{
Literatura
}

Abratowska A., Armeria maritima — gatunek roślin przystosowany do wzrostu na glebach skażonych metalami ciężkimi, „Kosmos” 2006, Vol. 55 (2-3), s. 217-227.

Federczyk W., Kosieradzka-Federczyk A., Ustawa o zapobieganiu szkodom w środowisku i ich naprawie. Komentarz, System Informacji Prawnej LEX 2013 (wersja elektroniczna).

Bulak P., et al., Hermetia illucens as a new and promising species for use in entomoremediation, „Science of The Total Environment” 2018, Vol. 633, s. 912-919, DOI: 10.1016/j.sci totenv.2018.03.252.

Sługocka M., Obowiązki przedsiębiorcy związane z korzystaniem ze środowiska, System Informacji Prawnej LEX 2020 (wersja elektroniczna).

Smolińska B., Metody oczyszczania gleb zanieczyszczonych rtęcia, ,Zeszyty Naukowe Politechniki Łódzkiej. Chemia Spożywcza i Biotechnologia” 2010, nr 74, s. 121-136.

Kiepas-Kokot A., Projekt planu remediacji — instrukcja sporządzenia, C.H.Beck Wydawnictwo Polska, Warszawa 2020.

Gruszecki K., Prawo ochrony środowiska. Komentarz, wyd. 5, System Informacji Prawnej LEX 2019 (wersja elektroniczna).

Prawo o odpadach. Wybrane problemy, red. B. Rakoczy, Wolters Kluwers Polska, Warszawa 2019.

Mateusz Hańderek

\section{Goals of remediation vs the role of accredited laboratories - practical aspects}

\author{
Summary
}

Article analyses issues connected with lack of specific regulations regarding performance of examinations by accredited laboratories in the process of remediation and possibilities for authorities to verify results of such examinations. In order to provide contest for the analysis, the article familiarizes the reader with short description of the remediation as a legal institution as well as the corresponding procedure. Article also includes de lege ferenda postulates in this respect.

Key words: environment protection pollution emissions remediation 
Матеуш Ханьдерек

\title{
Цели ремедиации и роль аккредитованных лабораторий — практические аспекты
}

\author{
Резюме
}

В статье анализируются проблемы, связанные с отсутствием подробных правил, касающихся проведения исследований аккредитованными лабораториями во время проведения ремидиации, и возможностей у органа осуществить проверку результатов этих исследований. Чтобы представить контекст рассмотрения, в статье также кратко представлены правовой институт ремидиации и сопутствующая процедура. В статье также содержатся постулаты с точки зрения законодательного предположения (de lege ferenda) в обсуждаемой области.

Ключевые слова: защита окружающей среды, загрязнения, выбросы, ремедиация

\section{Mateusz Hańderek}

\section{Obiettivi di risanamento e ruolo dei laboratori accreditati - aspetti pratici}

\section{Sommario}

L'articolo esamina i problemi legati alla mancanza di una regolamentazione specifica relativa all'esecuzione di test da parte di laboratori accreditati per l'esecuzione di bonifiche e alla capacità dell'autorità di verificare i risultati di tali test. Per inquadrare il contesto, l'articolo introduce anche brevemente l'istituto giuridico del risanamento e la procedura di accompagnamento. L'articolo contiene anche i requisiti de lege ferenda in questo settore.

Parole chiave: protezione dell'ambiente, inquinamento, emissioni, risanamento 